\title{
Synthesis of a Novel Class of Phosphonoaziridines as Interesting Antibacterial Agents
}

\author{
A. Keniche, A. Mezrai and J. Kajima Mulengi*
}

Laboratoire de Chimie Organique, Substances Naturelles et Analyses (COSNA), Université Aboubakr Belkaid-Tlemcen, P.O. Box 119 Tlemcen 13000, Algeria

\begin{abstract}
Aziridines constitute an interesting class of organic compounds because of their reactivity and the facility they can be converted into various derivatives. Our group has developed a new class of aziridines that show interesting biological activities such as antitumor and anti bacterial. This work describes new results of our ongoing research targeting new derivatives of biological interest.
\end{abstract}

Keywords: Aziridines, aza-Wittig, cancer, phosphonates, protease inhibitors, strained heterocycles.

\section{INTRODUCTION}

Heterocycles structures are found in so many fields of scientific investigation - including organic, inorganic, bioorganic, agricultural, industrial, pharmaceutical, and medicinal chemistry, as well as material science- that their importance can hardly be overemphasized [1]. Therefore a long lasting effort is maintained towards the development of new synthetic protocols for the preparation of those compounds and their numerous derivatives.

Of particular importance are aziridines because of their reactivity. They are valuable synthetic intermediates that are widely used to access numerous drugs and biologically active products [2-4]. Many aziridine alkaloids show anticancer, antibacterial, and/or antimicrobial and antileishmanial activities [5-8]. Some among them behave as potential protease inhibitors [9-10]. Therefore, an assumption might be made that the presence of an aziridine moiety in natural as well as synthetic compounds structures is essential to the observed activities [11]. As a result, several syntheses are found in the literature and it is beyond the scope of this work to mention all of them [12-25].

The biological activity of aziridines is highly related to the establishment of covalent bond with DNA [26]. In a previous work we reported the synthesis of aziridinyl derivatives [27] that had antitumor activities against breast cancer cells [28]. Such a behaviour was likely due to their capacity to strengthen and modulate the immune system [29]. Thus, going on with our efforts to develop new biologically active derivatives we replaced the phtaloyl group with a phosphonate moiety, with an aim to enlarging the scope of the already observed activities [30-32]. For all these reasons, the development of processes for the synthesis of functionalized aziridines containing a phosphorus substituent may represent a useful way to access interesting compounds that might play important therapeutic roles as already being observed in literature [33-38].

*Address correspondence to this author at the Laboratoire de Chimie Organique, Substances Naturelles et Analyses (COSNA), Université Aboubakr Belkaid-Tlemcen, P.O. Box 119 Tlemcen 13000, Algeria; Tel/Fax: 00213462158 86; E-mail: cosnalab@yahoo.fr
We report here the synthesis of new class of aziridines through two easily accessible procedures, the first using the reaction of diethylphosphonpropionic acid $\mathbf{1}$ with glycidol and the second referring to the coupling between an aziridinetosylate with an amino acid. This would provide us with an interesting starting material for further work.

\section{RESULT AND DISCUSSION}

\section{Syntheses}

During our investigation, the target compound was $7, " \mathrm{~N}$ (diethylphosphonopropionyl) -2-hydroxymethylaziridine (Fig. 1). Preliminary antibacterial assays revealed it to be endowed with interesting antibacterial activity against Escherichia coli, Staphylococus aureus, Pseudomonas aeruginosa, and Enterococcus faecalis. Needless to say that those strains are globally known to withstand treatment with common antibiotics and are the source of many nosocomal diseases.

It is worth mentioning that a simple replacement of a phtaloyl moiety with phosphonyl one entails a shift of activities from antiviral to antibacterial ones. Unfortunately, the assays could not be extended to other available compounds of the same family, since the investigator in charge of biological tests left the laboratory. Therefore, the work presented here represents the synthesis of some aziridines that will serve as starting materials for the preparation of hybrids, of which work is on course, along with partial results about biological assays.

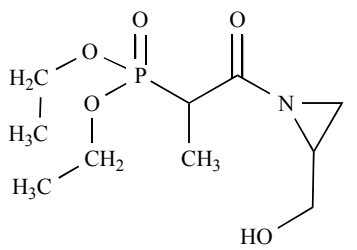

Fig. (1). Structures of Diethyl 1-(2-(hydroxymethyl)aziridin-1-yl)1-oxopropan-2-ylphosphonate.

The synthesis of 7 started from 2-bromopropionic methyl ester 2 that was previously distilled under reduced pressure 

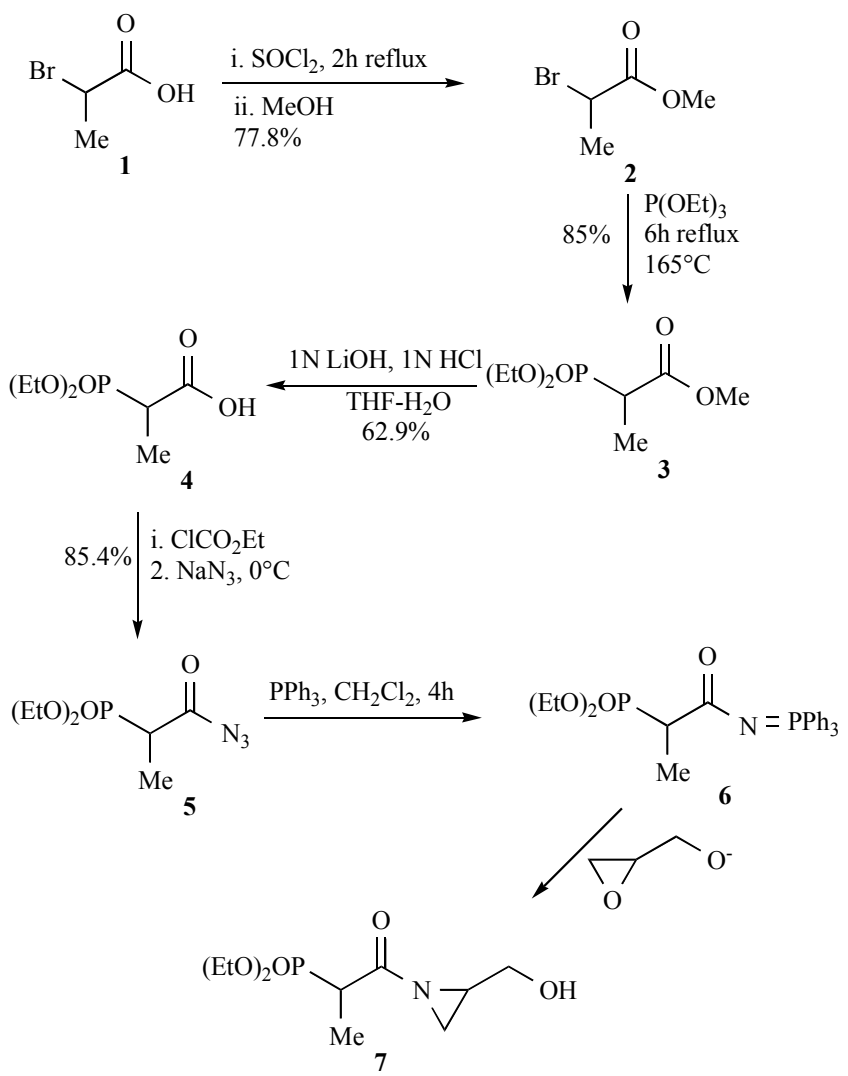

Scheme 1. Synthesis of $N$-(diethylphosphonopropionyl)-2-hydroxymethylaziridine.

to afford a colorless oil, before reacting with triethyl phosphite according to Arbuzov reaction, to afford the phosphonate $\mathbf{3}$ in good yield. $\mathbf{3}$ was hydrolyzed with a $1 \mathrm{~N}$ $\mathrm{LiOH}$ in tetrahydrofuran (THF)-water solution to yield 2(diethoxy phosphoryl)propionic acid 4.

The latter was converted into an acylazide 5, after reaction with ethyl chloroformate and sodium azide. The azide was used without further purification in the next step to yield the iminophosphorane. The generation of the nonisolated iminophosphorane was monitored by the evolution of nitrogen from the reaction solution.

Afterwards, glycidol alcoholate, in situ generated by treatment of glycidol with sodium hydride in dry ether, was dropwise added to the iminophosphorane solution. The reaction was left to proceed under nitrogen to yield the target compound. The reaction could be monitored by the progressive formation of a white solid corresponding to triphenylphosphine oxide, as could be checked later with an authentic commercial sample (Aldrich).

The conversion of an acyl azide into an aziridine is believed to occur according to mechanism we already suggested in our previous work [27]. After quenching the reaction mixture with an aqueous solution of ammonium chloride and removal of triphenylphosphine oxide, the compound was purified on a silica gel column using petroleum ether (b.p. $40-60^{\circ} \mathrm{C}$ )-dichloromethane. Satisfactory IR, ${ }^{1} \mathrm{H}-\mathrm{NMR}$, and ${ }^{13} \mathrm{C}-\mathrm{NMR}$ characteristics were obtained.

$N$-acylazide could also be prepared through a direct reaction of sodium azide in dimethylformamide (DMF) and with an acylchloride in dry dichloromethane, or according to a literature protocol [39].

As related to the synthesis of aziridines, we also prepared $\mathrm{N}$-acyl-2-tosylmethylaziridine from $\mathrm{O}$-tosylglycidol. The latter was first converted into an azido alcohol and further transformed into an aziridine by means of triphenylphosphine according to literature [40]. This compound showed more potent antibacterial activity as compared to compound 7. Probably the tosylate moiety could contribute to this enhanced activity, and this needs to be verified during further studies.

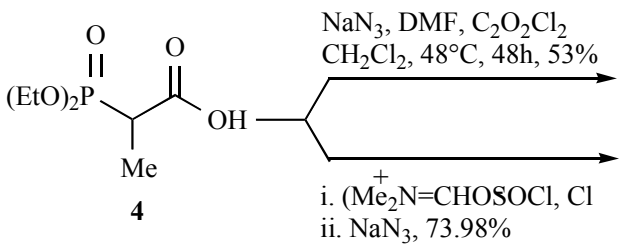<smiles>CCOP=O</smiles>

Scheme 2. Synthesis of Diethyl 1-azido-1-oxopropan-2-ylphosphonate. 


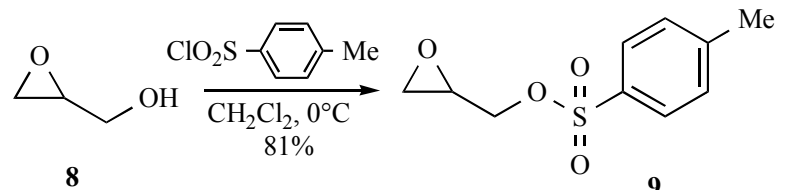

8

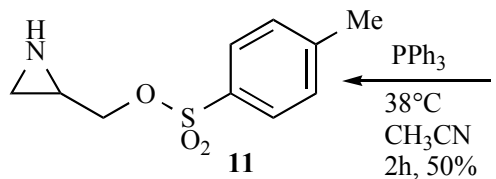

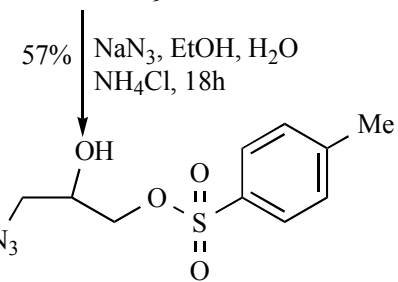

10

Scheme 3. Synthesis of aziridin-2ylmethylbenzensulfonate.

\section{Synthesis of aziridin-2ylmethylbenzensulfonate 11}

The $O$-protection of glycidol 8 with p-toluenesulfonyl chloride $(\mathrm{TsCl})$ in the presence of triethylamine (TEA), led to 9 in good yield (Scheme 3). The solution of 9 in ethanol and water was treated with ammonium chloride and sodium azide to give the azido alcohol $\mathbf{1 0}$ that was reacted in the next step with a solution of triphenylphosphine in anhydrous tetrahydrofuran (THF) to provide $\mathbf{1 1}$ in high yield. Compound 11 was purified on a silica gel column eluted with dichloromethane $\left(\mathrm{CH}_{2} \mathrm{Cl}_{2}\right)$-methanol $(\mathrm{MeOH})$ (v/v: $1: 1)$.

\section{Diethylphosphonopropionyl-2-tosylmethylaziridine 12}

Diethylphosphonopropionic acid was reacted either with thionyl chloride in the presence of TEA to yield an acyl chloride that was reacted with 11 to give $12(50 \%)$, or coupled in the presence of dicyclohexylcarbodiimide (DCC) with unprotected aziridine $\mathbf{1 1}$ to give the same compound in high yield $(90 \%)$.

This strategy enabled us use 2-methyltosylate aziridine 11 as building block to obtain different functionalized aziridines. The same approach was successfully applied to generate aziridines from $N$-phtaloylamino acids $\mathbf{1 3}$. Phenylalanine and tyrosine were chosen as a models, since in our initial work in this field [27], aziridine from the former amino acid showed the best biological profile [28], whereas tyrosine is claimed to behave as a residue of utmost importance in many receptors [41]. Derivatives 13 were prepared according to a modified literature procedure [42] and were recrystallized. They were further converted into aziridines 14 according to both methods previously described in the last section. After work-up, the phtaloyl group $(\mathrm{Ft})$ could be removed from the protected amino acid moiety of $14 \mathbf{a}$ by treatment with hydrazine hydrate according to literature [43], affording 15a with a free amino group for a potential peptide growth.

\section{Preliminary Biological Tests}

Compound 7 was submitted to biological assays on Pseudomonas aeruginosa ATCC 27853, Escherichia coli ATCC 25922 (gram negative bacteria), Staphylococcus aureus ATCC 25923, Enterococcus faecalis ATCC 29212 (gram positive bacteria). The assays were carried out by disc diffusion on agar medium, where compound 7 showed medium to medium activity on Pseudomonas aeruginosa, and a weak one on Staphylococus aureus. Gentamycin and Ciprofloxacin were used as references (Rahmoun, N. Unpublished results 2011. Détermination du pouvoir antibactérien d'une aziridene nouvellement synthétisée au Laboratoire COSNA).

As compared to the previous activity of phtaloyl aziridines, the results is interesting in such a way that it enables us modify or fix various groups on our aziridines to extend the scope of their biological activity. That is why compound $\mathbf{7}$ is already engaged in such a work. However, much work is still to be carried out on compound 7 and derivatives as related to assess as accurately as possible the Minimal Inhibitory Concentrations (MIC), the antibacterial effect versus concentration, as well as the biological pathway targeted by this aziridine and derivatives.

\section{CONCLUSION}

Numerous synthetic methods are found in the literature and allow easy accesses to various aziridines. It is worth

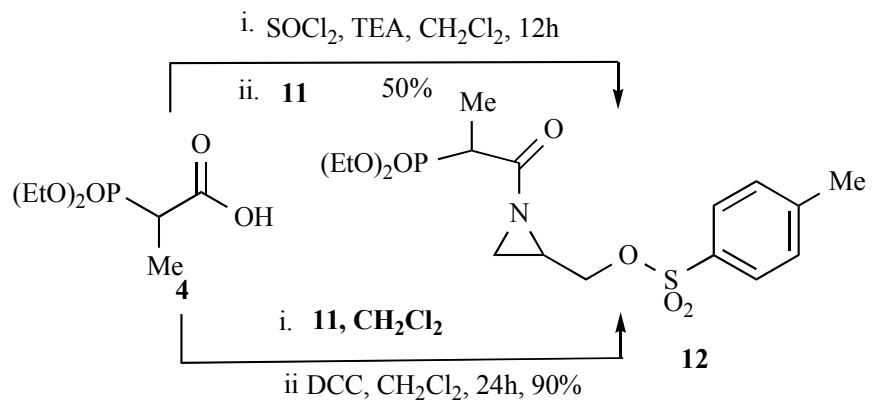

Scheme 4. Synthesis diethylphosphonopropionyl-2-tosylmethylaziridine. 

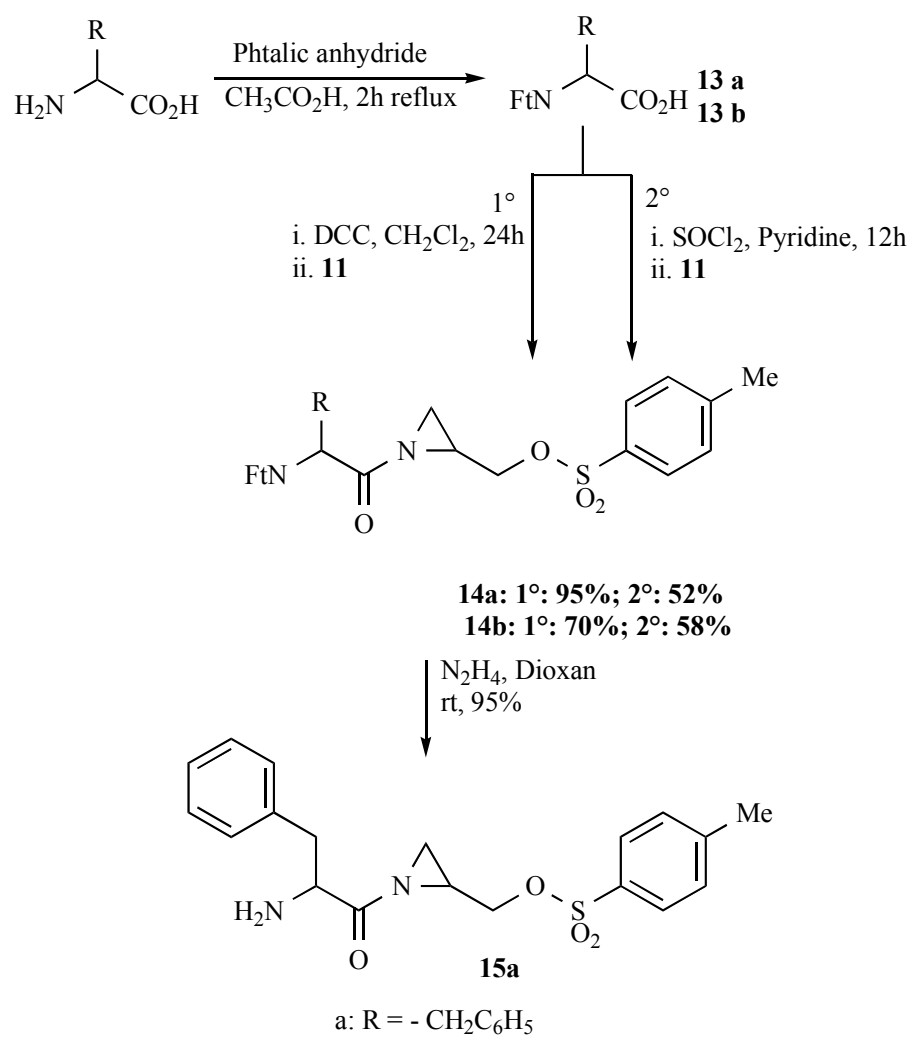

Scheme 5. Coupling of aziridines with Phenylalanine and Tyrosine.

mention that most of those methods are based on the conversion of an amino group into the corresponding aziridine. By contrast, our synthetic procedure targets the carboxylic group and its transformation into acyl aziridines, while the amino group is either protected or replaced by a phosphonate. As compared to our initial work [27], the present study has allowed us develop a second class of aziridines of interesting biological activities, represented by compound 7. The phtaloyl derivatives were active against breast cancer cells [28] whereas phosphonate showed antibacterial activitiy. Work is going on for the diversification of the initial work, especially for the search of targeted cancer chemotherapy, through the synthesis of hybrids.

\section{EXPERIMENTAL SECTION}

All the reactions with dry solvents were carried out under dry nitrogen. THF was dried over sodium /benzophenone and freshly distilled before use; $\mathrm{CH}_{2} \mathrm{Cl}_{2}$ was distilled and dried over phosphorus pentoxide $\left(\mathrm{P}_{2} \mathrm{O}_{5}\right)$. Triethylphosphite $\left.\mathrm{P}(\mathrm{OEt})_{3}\right)$ was distilled before use under reduced pressure. I.R spectra were collected from a Mattson Genesis II FTIR. NMR spectra were recorded in $\mathrm{CDCl}_{3}$ on a Bruker $300 \mathrm{MHz}$ instrument, using tetramethylsilane (TMS) as an internal standard. Chemical shifts are given in $\delta(\mathrm{ppm})$ and coupling constant (J) values in Hertz (Hz). CG analysis was performed on a Shimadzu 17A CPG chromatograph using a 30m DB-35 column. Melting points were determined on an Electrothermal T1A F3.15A instrument. Column chromatography was performed on silica gel 230-270 mesh (Merck) using $\mathrm{CH}_{2} \mathrm{Cl}_{2}, \mathrm{MeOH}$ and ether. Elemental analysis was performed only for solids on a LECO CHN 900 instrument.

\section{Methyl-2-bromopropionate 2}

To 2-bromopropionic acid $(20 \mathrm{~g}, 0.13 \mathrm{~mol})$, thionyl chloride $(23.32 \mathrm{~g}, 0.196 \mathrm{~mol})$ was added at room temperature. The reaction mixture was heated under reflux for $2 \mathrm{~h}$. The mixture was cooled and methanol $(0.261 \mathrm{~mol})$ was very slowly added with stirring and cooling, and the reaction was left for $30 \mathrm{~min}$. Excess methanol and thionyl chloride were removed in vacuo, and dichloromethane $(50 \mathrm{ml})$ was added. The organic layer was washed respectively with a $5 \%$ solution of sodium bicarbonate $(20 \mathrm{ml})$, a saturated solution of sodium chloride $(20 \mathrm{ml})$ and then dried over calcium sulfate. The dry solution was filtered and evaporated under vacuum to afford a residue that was purified by distillation under reduced pressure to afford a colorless oil (77.77\%). bp $\left.=50^{\circ} \mathrm{C}, 12 \mathrm{~mm} \mathrm{Hg},\right) ; \mathrm{IR} \mathrm{cm}^{-1}$ neat: $1743.95(\mathrm{C}=\mathrm{O}), 1160.03$ $(\mathrm{C}-\mathrm{O}), 673.81(\mathrm{C}-\mathrm{Br})$. $\mathrm{GC}$ analysis, retention time $(\mathrm{Rt})=$ $7.22 \mathrm{mn}$. ${ }^{1} \mathrm{H} \mathrm{RMN}, \delta \mathrm{CDCl}_{3} 300 \mathrm{MHz}: 1.95(\mathrm{~d}, \mathrm{~J}=6.5 \mathrm{~Hz}, 3 \mathrm{H}$, $\left.\mathrm{CH}_{3} \mathrm{CH}\right), 3.69\left(\mathrm{~s}, 3 \mathrm{H}, \mathrm{OCH}_{3}\right), 4.49\left(\mathrm{~s}, 2 \mathrm{H}, \mathrm{BrCH}_{2} \mathrm{CO}\right) .{ }^{13} \mathrm{C}$ $\mathrm{RMN}, \delta \mathrm{CDCl}_{3}: 23.90,50.87,160.02,190.90$

\section{Methyl 2-(diethoxy phosphoryl)propanoate 3}

Methyl 2-bromopropionate $(35 \mathrm{mmol})$ was introduced under nitrogen into a dry flask and then heated on reflux at $120^{\circ} \mathrm{C}$ in a fume cupboard. Triethylphosphite $(35 \mathrm{mmol})$ was slowly added over a period of $35 \mathrm{mn}$. When the addition was completed the reaction mixture was refluxed for $6 \mathrm{~h}$ and checked for completion by gas chromatography. At the end, the mixture was distilled under vacuo to afford a colorless oil. Yield $85 \%$; bp $=140^{\circ} \mathrm{C}, 12 \mathrm{mmHg}$; GC: retention time $24.25 \mathrm{mn} ; \mathrm{Rf}=0.32$ on silica gel plate $\mathrm{F}_{254}$ (Merck) $\mathrm{AcOEt} / \mathrm{CH}_{2} \mathrm{Cl}_{2}(5: 1)$. IR cm $\mathrm{cm}^{-1}$ neat $1740.16(\mathrm{C}=\mathrm{O}), 1165.95$ $(\mathrm{C}-\mathrm{O}), 1024.98(\mathrm{P}=\mathrm{O}), 965.51(\mathrm{P}-\mathrm{O})$. 
${ }^{1} \mathrm{H}$ RMN $\delta \mathrm{CDCl}_{3}$ 300MHz: $1.29\left(\mathrm{t}, \mathrm{CH}_{3} \mathrm{CH}_{2} \mathrm{OP}, J=1.5 \mathrm{~Hz}\right.$ ), 1.39 (d, $\left.\mathrm{CH}_{3} \mathrm{CH}, \mathrm{J}=7.5 \mathrm{~Hz}\right), 3.68\left(\mathrm{~s}, \mathrm{OCH}_{3}\right), 4.06\left(\mathrm{q}, \mathrm{CH}_{3} \mathrm{CH}\right.$, $\mathrm{J}=1.5 \mathrm{~Hz}), 4.11\left(\mathrm{q}, \mathrm{POCH}_{2} \mathrm{CH}_{3}, \mathrm{~J}=6.9 \mathrm{~Hz}\right)$.

${ }^{13} \mathrm{C} \mathrm{RMN}, \delta \mathrm{CDCl}_{3}: 3.45,16.29,43.98,50.99,62.19$, 169.97. ${ }^{31} \mathrm{P}$ RMN $\delta \mathrm{CDCl}_{3} 200 \mathrm{MHz}:-1\left({ }^{31} \mathrm{P}\right)$

\section{2-(diethoxy phosphoryl)propionic acid 4}

To a mixture of tetrahydrofuran and water $(\mathrm{v} / \mathrm{v}$ : $81 \mathrm{ml} / 40 \mathrm{ml})$, ester $(23 \mathrm{mmol})$ was introduced under magnetic stirring and an aqueous solution of $1 \mathrm{~N} \mathrm{LiOH}(24 \mathrm{mmol})$ was added. The mixture was stirred for $1 \mathrm{~h}$ at $0^{\circ} \mathrm{C}$ and left to stand overnight at room temperature. It was extracted with ethyl acetate; the aqueous layer was collected, and acidified with a $1 \mathrm{~N} \mathrm{HCl}$ aqueous solution to $\mathrm{pH} 2$. Extraction was then carried out with ethyl acetate; the aqueous solution was saturated with salt, and extracted for a last time. The organic extracts were combined, dried over $\mathrm{CaSO}_{4}$, filtered and concentrated in vacuo. Yield $62.96 \%$. IR cm ${ }^{-1}$ neat 3405.66 $(\mathrm{O}-\mathrm{H}), 1735.64(\mathrm{C}=\mathrm{O}), 1456.64(\mathrm{C}-\mathrm{O}), 1024.33(\mathrm{P}=\mathrm{O})$, 973.51 (P-O).

${ }^{1} \mathrm{H}$ RMN $\delta \mathrm{CDCl}_{3}$ 300MHz: $1.28\left(\mathrm{t}, \mathrm{CH}_{3} \mathrm{CH}_{2} \mathrm{OP}, \mathrm{J}=\right.$ $1.5 \mathrm{~Hz}), \quad 1.33\left(\mathrm{~d}, \mathrm{CH}_{3} \mathrm{CH}, \quad \mathrm{J}=7.2 \mathrm{~Hz}\right), \quad 3.68\left(\mathrm{q}, \mathrm{CH}_{3} \mathrm{CH}, \quad \mathrm{J}=\right.$ $1.5 \mathrm{~Hz}), 4.06\left(\mathrm{q}, \mathrm{POCH}_{2} \mathrm{CH}_{3}, \mathrm{~J}=6.9 \mathrm{~Hz}\right), 9.95(\mathrm{~s}, \mathrm{OH}) \cdot{ }^{13} \mathrm{C}$ $\mathrm{RMN}, \delta \mathrm{CDCl}_{3}: 3.19,16.29,46.48,176.99$.

\section{Diethyl 1-azido-1-oxopropan-2-ylphosphonate 5}

To a well stirred and cooled solution of carboxylic acid (13,5mmol), dry $\mathrm{CH}_{2} \mathrm{Cl}_{2}$, and dry TEA $(1.47 \mathrm{~g}, 14,6 \mathrm{mmol})$ were added under nitrogen. A solution of ethyl chloroformate $(2.058 \mathrm{~g}, 18,9 \mathrm{mmol})$ in dry $\mathrm{CH}_{2} \mathrm{Cl}_{2}$ was added over $15 \mathrm{~min}$. The reaction was allowed to react at $0-5^{\circ} \mathrm{C}$ for $20 \mathrm{~min}$ and a solution of sodium azide $(1.58 \mathrm{~g}, 24 \mathrm{mmol})$ in $10 \mathrm{ml}$ of cold water was added dropwise. After standing at $0^{\circ} \mathrm{C}$ for $1 \mathrm{~h}$, the mixture was poured onto crushed ice and extracted with $\mathrm{CH}_{2} \mathrm{Cl}_{2}(3 \times 50 \mathrm{ml})$. The combined organic layers were washed with water and dried over calcium sulfate. The solvent was removed under reduced pressure maintained at $40^{\circ} \mathrm{C}$ and the oily yellow residue was used in the next reaction without further purification. Yield: $85.41 \%$; IR IR $\mathrm{cm}^{-1}$ neat: $2138.10 \quad\left(\mathrm{~N}_{3}\right), \quad 1735.59(\mathrm{C}=\mathrm{O})$, 1024.75(P=O). ${ }^{1} \mathrm{H}$ RMN $\delta \mathrm{CDCl}_{3} 300 \mathrm{MHz}: 1.30(\mathrm{~d}, \mathrm{~J}=$ $\left.7.2 \mathrm{~Hz}, 3 \mathrm{H}, \mathbf{C H}_{3}\right), 1.39\left(\mathrm{t}, \mathrm{J}=6.9 \mathrm{~Hz}, 6 \mathrm{H}, \mathrm{OCH}_{2} \mathbf{C H}_{3}\right), 3.95$ (q, $\left.\mathrm{J}=7.2 \mathrm{~Hz}, 1 \mathrm{H}, \mathrm{O}=\mathrm{P}-\mathbf{C H}\left(\mathrm{CH}_{3}\right)-\mathrm{CON}_{3}\right), 4.10(\mathrm{q}, \mathrm{J}=6.9 \mathrm{~Hz}, 4 \mathrm{H}$, $\left.\mathrm{OCH}_{2} \mathrm{CH}_{3}\right) .{ }^{13} \mathrm{C} \mathrm{RMN}, \delta \mathrm{CDCl}_{3}: 3.79,16.29,42.98,61.77$, 179.78 .

Diethyl 1-(2-hydroxymethyl)aziridin-1-yl)-1-oxopropan2-ylphosphonate 7

\section{General Procedure}

\section{Solution $A$}

$\mathrm{N}$-acylazide $(4.04 \mathrm{~g}, 22,9 \mathrm{mmol})$ was introduced under nitrogen in a dry flask containing dry dichloromethane $(100 \mathrm{~mL})$. The solution was cooled $\left(0^{\circ} \mathrm{C}\right)$ and triphenylphosphine $(6.03 \mathrm{~g}, 22,9 \mathrm{mmol})$ was fractionally added and the solution was stirred for $2 \mathrm{~h}$.

\section{Solution B}

In a separate flask, sodium hydride $(0.6 \mathrm{~g}, 24,7 \mathrm{mmol})$ previously washed with ether was introduced in ether (50 $\mathrm{mL}$ ) and the suspension was stirred under nitrogen. A solution of glycidol $(1.7 \mathrm{~g}, 22,9 \mathrm{mmol})$ in dry ether $(50 \mathrm{~mL})$ was added dropwise over $20 \mathrm{~min}$ to the cooled suspension. After the addition was complete, the mixture was stirred for an additional $30 \mathrm{~min}$. Solution B was then siphoned off under nitrogen into a constant pressure dropping funnel mounted on the reaction flask containing solution A. B solution was then added dropwise to solution A, of which flask was cooled in an ice bath. The mixture was warmed up to $50^{\circ} \mathrm{C}$ for $1.5 \mathrm{~h}$ and cooled to room temperature. A $10 \%$ aqueous solution of ammonium chloride was added and the mixture was extracted with dichloromethane $(3 \times 25 \mathrm{~mL})$. The organic extracts were combined and dried over anhydrous $\mathrm{CaSO}_{4}$. After removal of the solvent, the residue was dissolved in icy anhydrous ether $(100 \mathrm{~mL})$ and triphenylphosphine oxide was filtered off under suction.

This operation was repeated until no solid separated from the ethereal solution. After removal of the solvent, the residue was purified on a silica gel column using petroleum ether (bp $40-60^{\circ} \mathrm{C}$ ) and dichloromethane (4:1). The resulting compound was stored in the cold under dry nitrogen. Crystallization occurred after standing at room temperature for 6 months (m.p. $\left.83^{\circ} \mathrm{C}\right)$. Yield: $62.38 \%$; IR cm ${ }^{-1}(\mathrm{KBr}$ pellet): $3473.52(\mathrm{O}-\mathrm{H}), 1669.65(\mathrm{C}=\mathrm{O}), 1022.52(\mathrm{P}=\mathrm{O})$.

${ }^{1} \mathrm{H} \mathrm{RMN} \delta \mathrm{CDCl}_{3} 300 \mathrm{MHz}: 1.22\left(\mathrm{~d}, \mathrm{CH}_{3}, \mathrm{~J}=3.3 \mathrm{~Hz}\right)$, $1.27\left(\mathrm{t}, \mathrm{CH}_{3} \mathrm{CH}_{2} \mathrm{OP}, \mathrm{J}=4.2 \mathrm{~Hz}\right), 1.34\left(\mathrm{~d}, \mathrm{CHCH}_{2} \mathrm{~N}, \mathrm{~J}=9 \mathrm{~Hz}\right)$; 2.99(m, CH), 3.29(dd, $\mathrm{CH}_{2} \mathrm{OH}, \mathrm{J}=1.2 \mathrm{~Hz}, \mathrm{~J}=0.6 \mathrm{~Hz}$ ), $3.31\left(\mathrm{dd}, \quad \mathrm{CH}_{2} \mathrm{OH}, \mathrm{J}=1.8 \mathrm{~Hz}, \mathrm{~J}=3.6 \mathrm{~Hz}\right), 3.64(\mathrm{~s}, \mathrm{OH})$, $4.11\left(\mathrm{q}, \mathrm{CH}_{3} \mathrm{CH}, \mathrm{J}=3.9 \mathrm{~Hz}\right), 4.18\left(\mathrm{q}, \mathrm{POCH}_{2} \mathrm{CH}_{3}, \mathrm{~J}=2.1 \mathrm{~Hz}\right)$. ${ }^{13} \mathrm{C} \quad \mathrm{RMN} \delta \mathrm{CDCl}_{3}: \quad 13.89\left(\mathrm{CH}_{3}\right), \quad 14.47\left(\mathrm{CH}_{3} \mathrm{CH}_{2}\right)$, $29.06\left(\mathrm{CH}_{2}\right), \quad 34.87(\mathrm{CH}), \quad 53.9(\mathrm{CH}), \quad 62.38 \quad\left(\mathrm{CH}_{2} \mathrm{O}\right)$, 77.09( $\mathrm{COH}), 170.63(\mathrm{C}=\mathrm{O})$.

Microanalysis: calcd for $\mathrm{C}_{10} \mathrm{H}_{20} \mathrm{NO}_{5} \mathrm{P}: \mathrm{C} 45.28 \%, \mathrm{H}$ $7.60 \%$ N 5.28\%. Found: C $45.24 \%$, H 7.59, N 5.25\%

\section{Oxiran-2-ylmethyl 4-methylbenzenesulfonate 9}

Dry triethylamine $(10.9 \mathrm{~g}, \quad 0.1081 \mathrm{~mol})$ and $\mathrm{p}$ toluenesulfonyl chloride $(20.61 \mathrm{~g}, 0.11 \mathrm{~mol})$ were added to a stirred solution of glycidol $(2 \mathrm{~g}, 27,02 \mathrm{mmol})$ in dry $\mathrm{CH}_{2} \mathrm{Cl}_{2}$, under nitrogen at $0^{\circ} \mathrm{C}$. The reaction mixture was stirred at room temperature overnight. After the reaction completion, the resulting mixture was diluted with $\mathrm{CH}_{2} \mathrm{Cl}_{2}$ and washed once with an aqueous solution of $\mathrm{NH}_{4} \mathrm{Cl}$. The organic layer was dried over $\mathrm{Na}_{2} \mathrm{SO}_{4}$, and the solvent removed under reduced pressure. The glycidol tosylate was obtained as a pasty mass in a good yield (81.16\%) IR $\mathrm{cm}^{-1} 1366.22(\mathrm{~S}=\mathrm{O})$, 1176.69 (C-O), 915.22 (S-O), 687.75-665.05 (OTs).

${ }^{1} \mathrm{H} \quad \mathrm{RMN} \delta \mathrm{CDCl}_{3} \quad 300 \mathrm{MHz}: 2.41\left(\mathrm{~s}, \mathrm{CH}_{3}\right), 2.55(\mathrm{~d}$, $\left.\mathrm{J}=13.8 \mathrm{~Hz}, 2 \mathrm{H}, \mathrm{CH}_{2}\right), 2.75(\mathrm{~m}, 1 \mathrm{H}, \mathrm{CH}), 3.89(\mathrm{dd}, \mathrm{J}=6.3 \mathrm{~Hz}$, $\left.\mathrm{J}=5.1 \mathrm{~Hz}, \mathrm{CH}_{2} \mathrm{OTs}\right), 4.2\left(\mathrm{dd}, \mathrm{J}=6.3 \mathrm{~Hz}, \mathrm{~J}=5.1 \mathrm{~Hz}, \mathrm{CH}_{2} \mathrm{OTs}\right)$, $7.3(\mathrm{~d}, \mathrm{~J}=8 \mathrm{~Hz}, 2 \mathrm{H}, \mathbf{A r}), 7.70(\mathrm{~d}, \mathrm{~J}=8 \mathrm{~Hz}, 2 \mathrm{H}, \mathbf{A r}) .{ }^{13} \mathrm{C} \mathrm{RMN} \delta$ $\mathrm{CDCl}_{3}: 21.29\left(\mathrm{CH}_{3}\right), 43.89,50.66,128.20,130.49,139.98$, 144.39 .

\section{3-azido-2-hydroxypropyl 4-methylbenzensulfonate 10}

A solution of glycidol $(2 \mathrm{~g}, 8,8 \mathrm{mmol})$ in ethanol $(20 \mathrm{ml})$ and water $(18 \mathrm{ml})$ was treated with ammonium chloride $(0.5 \mathrm{~g}, 9,61 \mathrm{mmol})$ and sodium azide $(0.62 \mathrm{~g}, 9,62 \mathrm{mmol})$. The resulting mixture was heated at $70-75^{\circ} \mathrm{C}$ during $18 \mathrm{~h}$. The mixture was cooled to room temperature and treated with a $5 \%$ aqueous sodium bicarbonate solution. Ethanol was removed in vacuo. The aqueous residue was extracted with ethyl acetate and the combined extracts were washed with 
brine and dried over anhydrous sodium sulfate. Filtration and concentration in vacuo afforded the azido alcohol (57\%). IR $\mathrm{cm}^{-1}$ : $3387.31(\mathrm{O}-\mathrm{H}), 1356.78(\mathrm{~S}=\mathrm{O}), 1177.09(\mathrm{C}-\mathrm{O}), 932.53$ (S-O), 714.5-667.07 (OTs).

${ }^{1} \mathrm{H} \mathrm{RMN} \delta \mathrm{CDCl}_{3}: 300 \mathrm{MHz}: 1.25\left(\mathrm{dd} \mathrm{CH}_{2} \mathrm{~N}_{3}, \mathrm{~J}=26.7 \mathrm{~Hz}\right.$, $1 \mathrm{H}, \mathrm{J}=7.2 \mathrm{~Hz}), 1.37\left(\mathrm{dd}, \mathrm{J}=26.7 \mathrm{~Hz}, \mathrm{~J}=7.2 \mathrm{~Hz}, 1 \mathrm{H}, \mathrm{CH}_{2} \mathrm{~N}_{3}\right)$, 2.48(s, $\left.\mathbf{C H}_{3}\right), 3.41(\mathrm{~m}, 1 \mathrm{H}), 3.54(\mathrm{~s}$ broad, $\mathrm{OH}), 4.10(\mathrm{dd}$, $\left.\mathrm{J}=16 \mathrm{~Hz}, 7.2 \mathrm{~Hz}, 1 \mathrm{H}, \mathrm{CH}_{2} \mathrm{CHOTsOH}\right), 4.26(\mathrm{dd}, \mathrm{J}=16 \mathrm{~Hz}$, $\left.7.2 \mathrm{~Hz}, 1 \mathrm{H}, \mathrm{CH}_{2} \mathrm{CHOTsOH}\right), 7.69(\mathrm{~d}, \mathrm{~J}=8.1 \mathrm{~Hz}, 2 \mathrm{H}, \mathrm{Ar})$, 7.37(d, J=8.1Hz, 2H, Ar).

${ }^{13} \mathrm{C} \mathrm{RMN} \delta \mathrm{CDCl}_{3}: 21.29,52.89,70.69,71.00,128.29$, $130.49,140.29,144.38$.

\section{Aziridin-2-ylmethylbenzensulfonate 11}

To a solution $(1.25 \mathrm{~g}, 4,99 \mathrm{mmol})$ of azido alcohol in anhydrous THF, a solution of triphenylphosphine $(1.33 \mathrm{~g}$, $5,06 \mathrm{mmol})$ in anhydrous THF was added dropwise. The addition was accompanied by a vigorous evolution of nitrogen. After nitrogen evolution has ceased. The solution was heated for $16 \mathrm{~h}$ under reflux at $70^{\circ} \mathrm{C}$ under nitrogen. The mixture was concentrated in vacuo to afford aziridine tosylate as a yellow oil $(90 \%)$. The oil was purified on a silica gel column using $\mathrm{CH}_{2} \mathrm{Cl}_{2}-\mathrm{MeOH}(1: 1)$. IR $\mathrm{cm}^{-1}$ neat: $3362.53(\mathrm{~N}-\mathrm{H}), 1363.15(\mathrm{~S}=\mathrm{O}), 1119.20(\mathrm{C}-\mathrm{O}), 931.10(\mathrm{~S}-$ O), 722.28-696.32 (OTs).

${ }^{1} \mathrm{H} \quad \mathrm{RMN} \delta \mathrm{CDCl}_{3}: 300 \mathrm{MHz}: 1.27(\mathrm{~s}, \mathrm{NH}), \quad 1.99(\mathrm{~d}$, $\left.\mathrm{J}=13.8 \mathrm{~Hz}, \mathbf{C H}_{2}\right), 2.26-2.34(\mathrm{~m}, \mathrm{CH}), 2.48\left(\mathrm{~s}, \mathbf{C H}_{3}\right), 3.66(\mathrm{dd}$, $\left.\mathrm{J}=13.2 \mathrm{~Hz}, \mathrm{~J}=4.5 \mathrm{~Hz}, 1 \mathrm{H}, \mathrm{CH}_{2} \mathrm{OTs},\right), 4.20(\mathrm{dd}, \mathrm{J}=13.2 \mathrm{~Hz}$, $\left.\mathrm{J}=4.5 \mathrm{~Hz}, 1 \mathrm{H}, \mathrm{CH}_{2} \mathrm{OTs}\right), 7.4\left(\mathrm{~d}, \mathrm{~J}=3 \mathrm{~Hz}, 2 \mathrm{H}, \mathrm{CH}_{2} \mathrm{OTs}\right)$, 7.60(d, J=3Hz, 2H, CH $\left.\mathbf{H}_{2} \mathrm{OTs}\right)$.

${ }^{13} \mathrm{C} \mathrm{RMN} \delta \mathrm{CDCl}_{3}: 21.29,22.68,29.79,76.28,128.27$, $130.48,140.29,144.39$.

\section{General Procedure for the Aziridinypeptides}

\section{Method 1}

To a well stirred and cooled solution of acid (1 equiv.), and 2-methyl aziridine tosylate (1equiv.) was added a solution of dicyclohexylcarbodiimide (DCC) (1 equiv.) in $\mathrm{CH}_{2} \mathrm{Cl}_{2}$, over period of $15 \mathrm{~min}$. The reaction was allowed to react at $0^{\circ} \mathrm{C}$ for $24 \mathrm{~h}$. At the end, the dicyclohexylurea (DCU) was filtered and washed with cold $\mathrm{CH}_{2} \mathrm{Cl}_{2}$. The organic layers were combined and dried over $\mathrm{CaSO}_{4}$. The solvent was removed under reduced pressure to afford a yellow oil was obtained in good $90 \%$ yield. The residue was purified on a silica gel column using petroleum ether $\left(45-46^{\circ} \mathrm{C}\right)-\mathrm{MeOH}$ $(1: 4)$.

\section{Method 2}

To a solution of the carboxylic acid (1 equiv) dissolved in $\mathrm{CH}_{2} \mathrm{Cl}_{2}, \mathrm{SOCl}_{2}$ (1 equiv.) was added slowly at room temperature. The reaction mixture was heated under reflux for $2 \mathrm{~h}$. Once the mixture was cooled, a solution of 2-methyl aziridine tosylate (1 equiv) in $\mathrm{CH}_{2} \mathrm{Cl}_{2}$ was added dropwise, and the reaction was left for $12 \mathrm{~h}$ at room temperature. The solvent was removed in vacuo, and dichloromethane $(50 \mathrm{ml})$ was added. The organic layer was washed with $20 \mathrm{ml}$ of brine and then dried over calcium sulfate, filtered and evaporated under vacuum to yield the aziridine. An example of identification is given for the compound obtained after the coupling of 2-(diethoxyphosphosryl)propionic acid with aziridine 11.

\section{Diethylphosphonopropionyl-2-tosylmethylaziridine 12}

IR $(\mathrm{KBr}): 1728.87(\mathrm{C}=\mathrm{O}), 1366.79(\mathrm{~S}=\mathrm{O}), 1119.96(\mathrm{C}-\mathrm{O})$, 1023.46(P=O), $932.07(\mathrm{~S}-\mathrm{O}), 723.31-695.46$ (OTs).

${ }^{1} \mathrm{H} \quad \mathrm{RMN} \quad \delta \mathrm{CDCl}_{3}, \quad 300 \mathrm{MHz}: \quad 1.27(\mathrm{~d}, \mathrm{~J}=5.1 \mathrm{~Hz}, \quad 3 \mathrm{H}$, $\left.\mathrm{CH}_{3} \mathrm{CH}\right), 1.29\left(\mathrm{t}, \mathrm{J}=7.1 \mathrm{~Hz}, 6 \mathrm{H}, \mathrm{CH}_{3} \mathrm{CH}_{2} \mathrm{OP}\right), 1.70(\mathrm{~d}, \mathrm{~J}=$ $\left.4.5 \mathrm{~Hz}, 2 \mathrm{H}, \mathrm{CH}_{2} \mathrm{~N}\right), 1.75-1.79(\mathrm{~m}, 1 \mathrm{H}, \mathrm{CHN}), 2.34(\mathrm{~s}, 3 \mathrm{H}$, $\left.\mathrm{CH}_{3} \mathrm{Ts}\right), \quad 3.68\left(\mathrm{dd}, \mathrm{J}=13.2 \mathrm{~Hz}, \mathrm{~J}=4.5 \mathrm{~Hz}, \quad \mathrm{CH}_{2} \mathrm{~N}\right), \quad 3.88(\mathrm{dd}$, $\left.\mathrm{J}=13.2 \mathrm{~Hz}, \mathrm{~J}=4.5 \mathrm{~Hz}, 1 \mathrm{H}, \quad \mathrm{CH}_{2} \mathrm{~N}\right), 4.01(\mathrm{q}, \mathrm{J}=3.9 \mathrm{~Hz}, 1 \mathrm{H}$, $\left.\mathrm{CHCH}_{3}\right), 4.09\left(\mathrm{q}, \mathrm{J}=2.4 \mathrm{~Hz}, 4 \mathrm{H}, \mathrm{POCH}_{2} \mathrm{CH}_{3}\right), 7.75(\mathrm{~d}, \mathrm{~J}=$ $3 \mathrm{~Hz}, 2 \mathrm{H}, \mathbf{A r}), 7.46(\mathrm{~d}, \mathrm{~J}=3 \mathrm{~Hz}, 2 \mathrm{H}, \mathbf{A r})$.

${ }^{13} \mathrm{C} \mathrm{RMN} \delta \mathrm{CDCl}_{3}: 4.38,16.29,21.28,29.35,30.56$, $42.51,61.78,73.58,128.25,130.48,144.76,177.19$.

\section{N-phtalimidophenylalanine 13a}

Phenylalanine $(0.121 \mathrm{~mol})$ was suspended in glacial acetic acid $(100 \mathrm{~mL})$ and phthalic anhydride $(0.12 \mathrm{~mol})$ was added. The mixture was refluxed for $2 \mathrm{~h}$ until all the solids dissolved and then cooled to room temperature and afterwards in an ice bath. The solid was filtered under suction and recrystallized from ethanol and water $(4: 1)$. The compound was identical to an authentic commercial sample from Aldrich. $\mathrm{mp}=183^{\circ} \mathrm{C}$ Yield: $83 \%$; IR $(\mathrm{KBr}): 3269.43$ $(\mathrm{O}-\mathrm{H}), 1771.55(\mathrm{C}=\mathrm{O}$ phtaloyl $), 1748.50(\mathrm{C}=\mathrm{O}) 1102.05(\mathrm{C}-$ O). ${ }^{1} \mathrm{H} \quad \mathrm{RMN} \delta \mathrm{CDCl}_{3}, 300 \mathrm{MHz}: 3.6\left(\mathrm{~d}, \mathrm{CH}_{2}, \mathrm{~J}=7.5 \mathrm{~Hz}\right)$, 5.24(t, CH, J=7.5Hz), 7.25(s, 5H，Ph $), 7.79(\mathrm{~s}, 4 \mathrm{H}, \mathbf{F t})$, 7.91 (s, $\left.\mathrm{CO}_{2} \mathrm{H}\right)$.

\section{N-Phtalimidotyrosine $13 \mathrm{~b}$}

The same procedure for the synthesis as above mentioned for 13a, except for the reflux time duration that was $24 \mathrm{~h}$.

$\mathrm{Mp}=149^{\circ} \mathrm{C} .{ }^{1} \mathrm{H} \mathrm{RMN} \delta \mathrm{CDCl}_{3}, 300 \mathrm{MHz}: 3.21(\mathrm{dd}, \mathrm{J}=$ $\left.8.5 \mathrm{~Hz}, 4.1 \mathrm{~Hz}, 1 \mathrm{H}, \mathrm{NCH}-\mathrm{CH}_{2}\right), 3.46(\mathrm{dd}, \mathrm{J}=8.5 \mathrm{~Hz}, 4.1 \mathrm{~Hz}$, $\left.1 \mathrm{H}, \mathrm{NCH}-\mathrm{CH}_{2}\right), 4.80(\mathrm{~m}, 1 \mathrm{H}, \mathrm{NCH}), 5.30(\mathrm{~s}, 1 \mathrm{H}, \mathrm{OH})$, $6.65(\mathrm{~d}, \mathrm{~J}=6.5 \mathrm{~Hz}, 2 \mathrm{H}, \mathrm{ArOH}), 7.08(\mathrm{~d}, \mathrm{~J}=6.5 \mathrm{~Hz}, 2 \mathrm{H}, \mathrm{ArOH})$, 7.80-7.84 (m, 4H, Ar).

${ }^{13} \mathrm{C} \mathrm{RMN} \delta \mathrm{CDCl}_{3}: 33.48,60.86,112.75,126.19,120.64$, 127.18, 128.17, 152.65, 171.69 .

(1-(2-(1,3-dioxoisoindolin-2-yl)-3-phenylpropanoyl)aziridin2-yl)methyl 4- methylbenzenzenesulfonate 14a

Pasty product. $1771.75(\mathrm{C}=\mathrm{O} \quad \mathrm{Ft}), \quad 1710.04 \quad(\mathrm{C}=\mathrm{O}$ aziridine $), \quad 1349.17(\mathrm{~S}=\mathrm{O}), 1186.10(\mathrm{C}-\mathrm{O}), \quad 723.93-683.38$ (OTs). ${ }^{1} \mathrm{H}$ RMN $\delta \mathrm{CDCl}_{3}, 300 \mathrm{MHz}: 1.66(\mathrm{dd}, \mathrm{J}=8.7 \mathrm{~Hz}, \mathrm{~J}=$ $4.5 \mathrm{~Hz}, 1 \mathrm{H}, \mathrm{NCH}), 1.41(\mathrm{dd}, \mathrm{J}=8.7 \mathrm{~Hz}, \mathrm{~J}=4.5 \mathrm{~Hz}, 1 \mathrm{H}, \mathrm{NCH})$, 1.71(m, 1H, NCH), 2.31(s, 3H, $\left.\mathrm{CH}_{3} \mathrm{Ph}\right), 3.21-3.84(\mathrm{~m}, 4 \mathrm{H}$, $\left.\mathrm{CH}_{2} \mathrm{Ph}, \mathrm{CH}_{2} \mathrm{O}\right), 5.16(\mathrm{~m}, 1 \mathrm{H}, \mathrm{CONCH}), 7.23-7.7 .26(\mathrm{~m}, 3 \mathrm{H}$, Ar), 4.36(d, J=6Hz, 2H), 7.81-7.86(m, 4H, Ar).

${ }^{13} \mathrm{C} \mathrm{RMN} \delta \mathrm{CDCl}_{3}: 18.29,26.38,27.57,32.01,57.28$, $70.56,120.65,122.85,125.62,126.55,129.17,136.18$, 141.38, 164.86. Elemental analysis: calcd for $\mathrm{C}_{27} \mathrm{H}_{24} \mathrm{~N}_{2} \mathrm{O}_{6} \mathrm{~S}$ : C $64.27 \%$, H 4.79\%, N 5.55\%. Found: C 63.87\%, H 4.75\%, N $6.01 \%$.

(1-(2-(1,3-dioxoisoindolin-2-yl)-3-(4-hydroxyphenyl)propanoyl)aziridin-2-yl) methyl 4- methylbenzenzene sulfonate $14 b$

$\mathrm{mp}=201^{\circ} \mathrm{C} . \mathrm{IR}(\mathrm{KBr}): 3328.41(\mathrm{O}-\mathrm{H}), 1775.61(\mathrm{C}=\mathrm{O}$ of $\mathrm{Ft}), 1626.75(\mathrm{C}=\mathrm{O}$ of aziridine $), 1311.81(\mathrm{~S}=\mathrm{O}), 1127.16(\mathrm{C}-$ O), 972.25 (S-O), 723.93-683.38 (OTs). 
${ }^{1} \mathrm{H}$ RMN $\delta . \mathrm{CDCl}_{3}, 300 \mathrm{MHz}: 1.36(\mathrm{dd}, \mathrm{J}=8.9 \mathrm{~Hz}, \mathrm{~J}=$ $4.1 \mathrm{~Hz}, 1 \mathrm{H}, \mathrm{NCH}), 1.64(\mathrm{dd}, \mathrm{J}=8.9 \mathrm{~Hz}, \mathrm{~J}=4.1 \mathrm{~Hz}, 1 \mathrm{H}, \mathrm{NCH})$, $1.70(\mathrm{~m}, 1 \mathrm{H}, \mathrm{NCH}), 2.31\left(\mathrm{~s}, 3 \mathrm{H}, \mathrm{CH}_{3} \mathrm{Ph}\right), 3.20(\mathrm{dd}, \mathrm{J}=8.5 \mathrm{~Hz}$, $\left.4.01 \mathrm{~Hz}, 1 \mathrm{H}, \mathbf{C} \mathbf{H}_{2} \mathrm{Ph}\right), 3.46(\mathrm{dd}, \mathrm{J}=8.5 \mathrm{~Hz}, 4.01 \mathrm{~Hz}, 1 \mathrm{H}$, $\left.\mathrm{CH}_{2} \mathrm{Ph}\right), 3.59\left(\mathrm{dd}, \mathrm{J}=7 \mathrm{~Hz}, \mathrm{~J}=3.5 \mathrm{~Hz}, 1 \mathrm{H}, \mathrm{CH}_{2} \mathrm{O}\right), 3.83(\mathrm{dd}, \mathrm{J}=$ $\left.7 \mathrm{~Hz}, \mathrm{~J}=3.5 \mathrm{~Hz}, 1 \mathrm{H}, \mathrm{CH}_{2} \mathrm{O}\right), 5.15(\mathrm{~m}, 1 \mathrm{H}, 1 \mathrm{H}, \mathrm{NCHCO})$, 5.30(s, broad, $1 \mathrm{H}, \mathrm{OH}), 7.24-4.26(\mathrm{~m}, 4 \mathrm{H}, \mathrm{ArOH}, \mathrm{Ph})$, $7.36(\mathrm{~d}, \mathrm{~J}=6 \mathrm{~Hz}, 2 \mathrm{H}, \mathrm{Ph}), 7.83-7.85(\mathrm{~m}, 4 \mathrm{H}, \mathrm{Ar}) .{ }^{13} \mathrm{C} \mathrm{RMN} \delta$ $\mathrm{CDCl}_{3}: 18.27,26.35,32.19,57.18,70.55,112.75,115.09$, $120.66,125.29,127.49,129.08,141.39,151.65,164.85$,

Elemental analysis: calcd for $\mathrm{C}_{27} \mathrm{H}_{24} \mathrm{~N}_{2} \mathrm{O}_{7} \mathrm{~S}$ : C $62.30 \%, \mathrm{H}$ $4.65 \%$, N 5.38\%. Found: C 61.99, H 5.01\%, N 5.32\%.

\section{N-phenylalanyl-2-tosylmethylaziridine 15a}

$\mathrm{mp}=198^{\circ} \mathrm{C} . \mathrm{IR}(\mathrm{KBr}):(\mathrm{N}-\mathrm{H}), 1659.13(\mathrm{C}=\mathrm{O}$ aziridine $)$, 1329.22(S=O), 1081.37 (C-O), $965.45 \quad(\mathrm{~S}-\mathrm{O}), 720.13-$ 682.09 (OTs).

${ }^{1} \mathrm{H} \mathrm{RMN} \delta \mathrm{CDCl}_{3} 300 \mathrm{MHz}: 1.28(\mathrm{dd}, \mathrm{J}=5.1 \mathrm{~Hz}, \mathrm{~J}=2.1 \mathrm{~Hz}$, $\left.1 \mathrm{H}, \mathrm{NCH}_{2} \mathrm{CH}\right), 1.72\left(\mathrm{dd}, \mathrm{J}=5.1 \mathrm{~Hz}, \mathrm{~J}=2.1 \mathrm{~Hz}, 1 \mathrm{H}, \mathrm{NCH}_{2} \mathrm{CH}\right)$, $1.78-1.81\left(\mathrm{~m}, 1 \mathrm{H}, \mathrm{NCH}_{2} \mathrm{CH}\right), 2.48\left(\mathrm{~s}, 3 \mathrm{H}, \mathbf{C H}_{3}\right), 3.24(\mathrm{~d}, \mathrm{~J}=$ $\left.3.9 \mathrm{~Hz}, 1 \mathrm{H}, \mathrm{CH}_{2} \mathrm{Ph}\right), 3.26\left(\mathrm{~d}, \mathrm{~J}=3.9 \mathrm{~Hz}, 1 \mathrm{H}, \mathrm{CH}_{2} \mathrm{Ph}\right), 3.55(\mathrm{dd}$, $\left.\mathrm{J}=8.1 \mathrm{~Hz}, \quad \mathrm{~J}=2.7 \mathrm{~Hz}, \quad 1 \mathrm{H}, \quad \mathrm{CH}_{2} \mathrm{OTs}\right), \quad 3.76(\mathrm{dd}, \quad \mathrm{J}=8.1 \mathrm{~Hz}$, $\mathrm{J}=2.7 \mathrm{~Hz}, 1 \mathrm{H}, \mathrm{CH}_{2} \mathrm{OTs}$, ), 4.14-4.18(m, $\left.1 \mathrm{H}, \mathrm{PhCH}_{2} \mathrm{CHNH}_{2}\right)$, $5.44\left(\mathrm{~d}, \mathrm{~J}=1.5 \mathrm{~Hz}, 2 \mathrm{H}, \mathrm{CHNH}_{2}\right), 7.28(\mathrm{~d}, \mathrm{~J}=4.2 \mathrm{~Hz}, \mathrm{Ph}), 7.30(\mathrm{~d}$, $\mathrm{J}=1.8 \mathrm{~Hz}, 2 \mathrm{H}, \mathrm{Ph}), 7.41(\mathrm{t}, \mathrm{J}=1.2 \mathrm{~Hz}, 2 \mathrm{H}, \mathrm{Ph}), 7.47(\mathrm{~d}, \mathrm{~J}=1.5 \mathrm{~Hz}$, $2 \mathrm{H}, \mathrm{Ts}), 7.76(\mathrm{~d}, \mathrm{~J}=3 \mathrm{~Hz}, 2 \mathrm{H}, \mathrm{Ts})$.

${ }^{13} \mathrm{C} \mathrm{RMN} \delta \mathrm{CDCl}_{3}: 16.29,25.39,24.38,25.37,34.01$, $46.55,110.75,126.28,124.18,125.48,135.27,140.36$, 150.66 .

Elemental analysis: calcd for $\mathrm{C}_{19} \mathrm{H}_{22} \mathrm{~N}_{2} \mathrm{O}_{5} \mathrm{~S}$ : C $58.45 \%, \mathrm{H}$ $5.68 \%$, N 7.17\%. Found C 57.56\%, H 5.70\%, 6.99\%.

\section{ACKNOWLEDGEMENTS}

We are indebted to General Directorate for Scientific Research and Technological Development (DGRS-DT), Ministry of Higher Education and Scientific Research (Algeria) for the financial support of this work. We are also grateful to Rahmoun Nadjib of Laboratoire Antibiotiques Antifongiques: physico-chimie, synthèse et activité biologique for preliminary biological assays.

\section{REFERENCES}

[1] Cella, R.; Stefani, H.A. Ultrasound in heterocyclic chemistry. Tetrahedron., 2009, 65, 2619-2641.

[2] Sweeney, J.B. Aziridines, epoxides ugly cousins? Chem. Soc. Rev., 2002, 31, 247-258

[3] (a)Smith, B.; Doran, A.C.; Mclean, S.; Tingley, F. D.; Neill, B. T.; Kajiji, S. M. P-Glycoprotein efflux at the blood-brain barrier mediates differences in brain disposition and pharmacodynamics between two structurally related neurokin-1 receptor antagonists. J.Pharmacol.Exp.Ther., 2001, 298, 1252-1259; (b) Naito, M.; Matsuba, Y.; Sato. S.; Hirata H.; Tsuruo, T. MS-209, A quinolinetype reversal agent potentiates antitumor efficacy of docetaxel in multidrug-resistant solid tumor xenograft models. Clin.Cancer Res., 2002, 8, 582-588.

[4] Prosser, G.A.; Patterson, A.V.; Ackereley, D.F. uvrB gene deletion enhances SOS chromotest sensitivity for nitroreductases that preferentially generate the 4-hydroxylamine metabolite of the anticancer prodrug CB1954. J. Biotechnol., 2010, 150, 190-194.

[5] Fahey, K.; Aldabbagh, F. The influence of the aziridinyl substituent of benzimidazoles and benzimidazolequinones on toxicity towards normal and Fanconi anaemia cells. Tetrahedron Lett., 2008, 49, 5235-5237.

[6] Fahey, K.; O’Donovan, L.; Carr, M.; Carty, M.P.; Aldabbagh, F. Synthesis and toxicity towards normal and cancer cell lines of benzimidazolequinones containing fused aromatic rings and 2aromatic ring substituents. Eur. J. Med. Chem., 2010, 45, 18731879.

[7] Prosser, G.A.; Copp. J. N.; Syddall, S.P.; Williams, E. M.; Smaill, J. B.; Wolson, W.R.; Patterson, A.V.; Ackerley, D.F. Discovery and evaluation of Escherichia coli nitroreductases that activate the anti-cancer prodrug CB1954. Biochem. Pharmacol., 2010, 79, 678687.

[8] Sucre, A.P.; Vicik, R.; Schultheis, M.; Schirmeister,T.; Moll, H. Aziridine-2,3-dicarboxylates, peptidomimetic cysteine protease inhibitors with antileishmanial activity, antimicrobial. Agents Chemother., 2006, 50, 2439-2447.

[9] Hanessian, S.; Moitessier, N.; Cantin, L.D. Design and synthesis of MMP inhibitors using $N$-arylsulfonylaziridine hydroxamic acids as constrained scaffolds. Tetrahedron., 2001, 57, 6885-6900.

[10] Schirmeier, T.; Peric, M. Aziridinyl peptides as inhibitors of cysteine proteases: effect of a free carboxylic acid function on inhibition. Bioorg. Med. Chem., 2000, 8, 1281-1291.

[11] Ismail, M.D.; Levitsky, D.O.; Dembitsky, V.M. Aziridine alkaloids as potential therapeutic agents. Eur. J. Med. Chem. 2009, 44, 33733387.

[12] Filigheddu, S. N.; Taddei, M. Small ring constrained peptidomimetics. Synthesis of aziridine parallel $\beta$-sheet mimetics. Tetrahedron Lett., 1998, 39, 3857-3860.

[13] Xu, W.; Guo, H.; Zhu, Q.; Ke, X.; Hu, X. Asymmetric borane reduction of prochiral ketones catalyzed by $\alpha, \alpha$-disubstituted aziridinemethanols. Catal Lett., 2008, 125, 302-307.

[14] Sousa, J.; Prabhakar, S.; Lobo, A. M.; Rosa, A. M.; Gomes, M.J.S.; Corvo, M.C.; Williams,D.J.; White, A.J. P. Asymmetric. synthesis of $\mathrm{N}$-aryl aziridines. Tetrahedron: Asymmetry, 2001, 12, 33493365 .

[15] Haga, T.; Ishikawa, T. Mechanistic approaches to asymmetric synthesis of aziridines from guanidinium ylides and aryl aldehydes. Tetrahedron, 2005, 61, 2857-2869.

[16] Cardillo, G.; Fabbroni, S.; Gentilucci, L.; Gianotti, M.; Perciaccante, R.; Selvan, S.; Tolomelli, A. Enantioselective synthesis of aziridine 2,2-dicarboxylates. Part II: Determination of the absolute configuration. Tetrahedron: Asymmetry, 2002, 13, 1411-1415.

[17] Shinkevich, E.Y.; Tehrani, K.A.; Khlebnikov, A.F.; Novikov, M.S. Synthesis and reactivity of 3-(2-chloroalkyl)-2,2-dihaloaziridines. Tetrahedron, 2008, 64, 7524-7530.

[18] Arini, L. G.; Sinclair, A.; Szeto, P.; Stockman, R. A. Direct synthesis of aliphatic vinyl aziridines. Tetrahedron Lett., 2004, 45, $1589-1591$

[19] Cardillo, G.; Fabbroni, S.; Gentilucci, L.; Gianotti, M.; Perciaccante, R.; Tolomelli,A. Enantioselective synthesis of aziridine 2,2-dicarboxylates. Part I: Copper(II)-bisoxazoline complex-catalysed Michael reaction on alkylidene malonates. Tetrahedron: Asymmetry, 2002, 13, 1407-1410.

[20] Breuning, A.; Vicik, R.; Schirmeister, T. An improved synthesis of aziridine-2,3-dicarboxylates via azido alcohols-epimerization studies. Tetrahedron: Asymmetry, 2003, 14, 3301-3312.

[21] Teresa Barros, M.; Maycock, C.D.; Ventura,M.R. A synthesis of aziridines from $\alpha$-iodoenones. Tetrahedron Lett., 2002, 43, 43294331.

[22] Xue,Z.; Mazumdar, A.; Hope-Weeks, M.J.; Mayer, M.F. Aziridine synthesis in the presence of catalytic amounts of pyridiniums or viologens. Tetrahedron Lett., 2008, 49, 4601-4603.

[23] Sweeney, B.J.; Cantrill, A. A.; Mclaren, A.B.; Thobhani, S. Asymmetric aziridine synthesis by aza-Darzens reaction of $N$ diphenylphosphinylimines with chiral enolates. Part 1: Formation of cis-aziridines. Tetrahedron, 2006, 62, 3681-3693.

[24] Adamo ,M. F.; Bruschi, S.; Suresh, S.; Piras, L. Aziridination of 3methyl-4-nitro-5-styrylisoxazoles. Tetrahedron Lett., 2008, 49 , 7406-7409.

[25] Duan, P. W.; Chiu, C.C.; Lee, W. D.; Pan, L. S.; Venkatesham, U.; Tzeng, Z. H.; Chen, K. On the scope of diastereoselective aziridination of various chiral auxiliaries derived $\mathrm{N}$ - and $\mathrm{O}$-enones with $N$-aminophthalimide in the presence of lead tetraacetate. Tetrahedron: Asymmetry, 2008, 19, 682-690.

[26] Sharma, P.; Kumar, A.; Upadhyay, S.; Sahu, V.; Singh, J. Synthesis and QSAR modeling of 2-acetyl-2-ethoxycarbonyl-1-[4(4'arylazo)-phenyl]- $N, N$-dimethylaminophenyl aziridines as potential antibacterial agents. Eur. J. Med. Chem., 2009, 44, 251-259. 
[27] Medjahed, W.; Tabet Zatla, A.; Kajima Mulengi,J.; Baba Ahmed,F.Z.; Merzouk, H. The synthesis of $N$-acyl-2hydroxymethyl aziridines of biological interest. Tetrahedron Lett., 2004, 45, 1211-1213.

[28] Baba Ahmed, F. Z.; Bouanane, S.; Merzouk, S. A.; Merzouk, H.; Medjahed, W.; Kajima Mulengi,J.; Prost, J. 2-hydroxymethyl-1-(Nphtaloyltriptophyl)aziridine stimulates in vitro human lymphocyte proliferation and interleukin secretion. Pathol. Biol., 2008, 56, 137-142.

[29] Baba Ahmed, F.Z.; Merzouk, H.; Bouanane, S.; Benkalfat, N. B.; Merzouk, S.A.; Kajima Mulengi, J.; Narce, M. Evaluation de la toxicité aiguë de la 2-hydroxyméthyl-1(Nphtaloyltryptophyl)aziridine chez le rat Wistar. Ann Toxicol Anal. 2010, DOI: $10.1051 /$ ata/2010017. www.ata-journal.org

[30] (a)- Fields, S.C. Synthesis of natural products containing a C-P bond. Tetrahedron.,1999, 55, 12237-12273; (b) Grif, K.; Dierich, M. P.; Pfaller, K.; Miglioli, P. A.; Allenberger, F. In vitro activity of fosfomycin in combination with various antistaphylococcal substances. J. Antimicrob. Chemother., 2001, 48, 209-217.

[31] (a) Hata, T.; Koja, F.; Sano,Y.; Kanamori, K.; Matsumae, A.; Sugawara, R.; Hoshi, T.; Shima, T.; Ito, S.; Tomizawa, S. Carzinophilin, a new tumor inhibitory substance produced by streptomyces. I.: J Antibiot., 1954, 7, 107-112.; (b) Smith, A. B.; Yager, K. M.; Taylor, C. M. Enantioselective synthesis of diverse .alpha. amino phosphonate diesters. J. Am.Chem. Soc., 1995, 117, 10879-10888.

[32] (a) Smithrud, D. B.; Benkovic, P. A.; Benkovic, S. J.; Taylor, C. M.; Yager, K. M.; Witherington, J.; Phillips, B. W.; Sprengler, P. A.; Smith, A. B.; Hirschmann, R. Investigations of an Antibody Ligase. J. Am. Chem. Soc., 1997, 119, 278-282; (b) Hirschmann, R.; Smith, A. B.; Taylor, C. M.; Benkovic, P. A.; Taylor, S. D.; Yager, K. M.; Spengler, P. A.; Benkovic, S. J. Peptide synthesis catalyzed by an antibody containing a binding site for variable amino acids. Science., 1994, 265, 234-237; (c) Meyer, J. H.; Bartlett, P. A. Macrocyclic inhibitors of penicillopepsin .1. Design, synthesis, and evaluation of an inhibitor bridged between $\mathrm{P} 1$ and P3. J. Am. Chem. Soc., 1998, 120, 4600-4609; (d) Chackalamannil, S.; Chung, S.; Atamford, A. W.; McKittrick, B. A.; Wang, Y.; Tsai, H.; Cleven, R.; Fawzi, A.; Czarniecki, M. Highly Potent and selective inhibitors of endothelin converting enzyme. Bioorg. Med.Chem. Lett., 1996, 6, 1257-1260; (e) Steere, J. A.; Sampson, P. B.; Honek, J. F. Synthesis of an alpha-aminophosphonate nucleoside as an inhibitor of S-adenosyl-L-homocysteine hydrolase. Bioorg. Med. Chem. Lett., 2002, 12, 457-460; (f)
Cristau, H. J.; Coulombeau, A.;Genevis-Borella, A.; Pirat, J. L. A convenient one-pot synthesis of phosphino-dipeptide analogs. Tetrahedron Lett., 2001, 42, 4491-4494.

[33] Dolence, E.K.; Roylance,J. B . Opticallly active diethyl $N$-(ptoluenesulfonyl)-aziridine 2-phosphonates as chiral synthons for the synthesis of $\beta$-substituted $\alpha$-amino phosphonates. Tetrahedron: Asymmetry., 2004, 15, 3307-3322.

[34] D.Y. Kim, D.Y. Rhie. Synthesis of $\alpha$-aminoalkylphosphonates from vinylphosphonates via aziridinylphosphonates. Tetrahedron., 1997, 53, 13603-13608.

[35] Sykora, J.; Karban, J.; Cisarova, I.; Hilgard, S. Molecular structure of eight possible configurational isomers of 2,3- and 3,4-epimino derivatives of 1,6-anhydro- $\beta$-D-hexopyranoses: conformation analysis, intra- and inter-molecular hydrogen bonds. Carbohydrate Res., 2008, 343, 2789-2796.

[36] Stevens, C.; Gallant, M.; De Kimpe, N. Synthesis of 1-phosphono2-aza-1,3-dienes and their conversion into 1-vinyl-2-phosphono aziridines. Tetrahedron Lett., 1990, 40, 3457-3460.

[37] Hodgson, D.M.; Xu, Z. $\alpha, \beta$-Aziridinylphosphonates by lithium amide-induced phosphonyl migration from nitrogen to carbon in terminal aziridines. J.Org.Chem., 2010, 6, 978-983.

[38] Bartnik, R.; Lesniak, S.; Wasiak, P. 1,3-Dipolar addition of diethyl diazomethylphosphonate onto a $\mathrm{C}=\mathrm{N}$ double bond. Synthesis of triazolinyl and aziridinyl phosphonates. Tetrahedron Lett., 2004, $45,7301-7302$

[39] Arrieta, A.; Aizpurua, J. M.; Palomo, C. $N, N-$ Dimethylchlorosulfitemethaniminium chloride $\left(\mathrm{SOCl}_{2}-\mathrm{DMF}\right)$ a versatile dehydrating reagent. Tetrahedron Lett., 1984, 25, 33653368.

[40] Rohloff, J.C.; Kent, K.M.; Postich, M.J.; Becker, M.W.; Chapman, H.; Kelly, D.E.; Lew, W.; Louie, M.S.; McGee, L.R.; Prisbe, E.J.; Schultze, L.M.; Yu, R.H.; Zhang, L. Practical total synthesis of the anti-influenza drug GS-4104. J. Org. Chem., 1998, 63, 4545-4550.

[41] Koide, S; Sidhu, S. The importance of being tyrosine: lessons in molecular recognition from minimalist synthetic binding proteins. ACS Chem. Biol., 2009, 4(5), 325-334

[42] Applegate, H. E.; Cimarusti, C. M.; Dolfini, J. E.; Funke, P. T.; Koster, W. H.; Puar, M. S.; Slusarchyk, W. A.; Young, M. G. Synthesis of 2-, 4-, and 7-methylthio-substituted cephalosporins. $J$. Org. Chem., 1979, 44, 811-818.

[43] Nisalo, D.; Frigerio, M. Synthèse de l'amino-3 azétidine. $J$. Heterocycl. Chem., 1985, 22, 961-963.

(C) Keniche et al.; Licensee Bentham Open.

This is an open access article licensed under the terms of the Creative Commons Attribution Non-Commercial License (http://creativecommons.org/licenses/by-nc/3.0/) which permits unrestricted, non-commercial use, distribution and reproduction in any medium, provided the work is properly cited. 